\title{
Political parties in Northern Ireland and the post-Brexit constitutional debate
}

\author{
David Mitchell, Assistant Professor, Conflict Resolution and Reconciliation \\ Trinity College Dublin at Belfast \\ damitche@tcd.ie
}

This chapter will appear in Oran Doyle, Aileen McHarg, Jo Murkens (eds.), The Brexit Challenge for Ireland and the United Kingdom: Constitutions under Pressure (Cambridge, Cambridge University Press, 2021).

The implementation of the 1998 'Good Friday' or 'Belfast' Agreement entailed the stabilising of Northern Ireland's place within the United Kingdom. Although anti-Agreement unionists and pro-Agreement republicans claimed that the Agreement was a stepping stone to Irish unity, the addressing of Irish nationalist grievances through the reform of governance in Northern Ireland, alongside growing North-South links and British-Irish co-operation, ensured that Northern nationalist interest in Irish unity in the short term remained relatively low. This equilibrium was upset in 2016 by the desire of the UK - predominantly England - to leave the European Union. This prospect imposed a new binary on Northern Ireland politics which interacted with the constitutional divide in complex ways. This interaction is the focus of this chapter.

It begins by reviewing the position of the five main parties on Europe prior to 2016. It explains the parties' stances during the referendum campaign and examines how the parties 
responded to the referendum result. Following this, the chapter argues that Brexit produced constitutional restlessness in Northern Ireland because the vote lacked legitimacy according to the standards of consent contained in the Agreement. The chapter then traces how the new constitutional debate became established, highlighting how, although the debate was initiated by Brexit, it was intensified by subsequent developments in British and Irish politics. The chapter also explores key dilemmas that the debate posed for the political parties. The conclusion suggests that constitutional deliberations look set to continue but possibly at a lower intensity. Their direction will be shaped by developments in 2019-20 including the Boris Johnson Brexit agreement, the new Irish government, the restoration of devolution in Northern Ireland, and the coronavirus crisis.

\section{The Northern parties and Europe before Brexit}

The thrust of European integration towards the pooling of national sovereignty and the weakening of national borders has had a distinct resonance in a region in which public opinion on sovereignty and borders has been polarised to the point of violence. For at least two decades after the UK and Ireland joined the European Economic Community (EEC), the militants of the Irish Republican Army (IRA) were engaged in a low-intensity armed conflict against the British state designed to weaken London's commitment to retaining Northern Ireland. ProBritish loyalist paramilitaries sought to defend the status quo through a violent campaign directed at the IRA and what loyalists saw as its (Catholic) support base. At the same time, the

very structure of the Northern Ireland party system was, and it still is, based on competing views of the legitimacy of the Irish border. It has been called an 'ethnic dual party system' because most people vote according to their community background and competition for votes 
mainly occurs within, rather than between, each of the two main blocs. ${ }^{1}$ (This description may need updating given the leap of the cross-community Alliance Party from fifth to third largest party in elections in 2019). Accordingly, Europe and European issues played little role in party politics before Brexit. In a 2010 study of the 'Europeanisation' of politics in Ireland, Murphy and Hayward found that,

Northern Ireland's political parties have largely proved more resistant to Europeanizing influences than their counterparts elsewhere. In this respect, there is little evidence of radically changed attitudes towards Europe among Northern Ireland's political parties, nor is there any strong basis for suggesting that they have treated the EU as an essential arena for broadening political opportunities. ${ }^{2}$

Rather, Europe was refracted through the all-consuming conflict over the constitutional status of Northern Ireland.

Despite some policy differences and electoral competition between the Democratic Unionist Party (DUP) and Ulster Unionist Party (UUP) on Europe, the parties' outlooks on Europe have had much in common. From the debates on initial accession to the EEC in 1974 right up to Brexit, to varying degrees, Europe has been perceived by many unionists as a threat to British sovereignty. The threat is twofold. First, unionists are deeply attached to British political institutions, meaning that the possibility of European institutions constraining the primacy of Westminster was viewed as threatening. Second, unionists feared that British sovereignty over Northern Ireland could be weakened through the encroachment of Irish influence across the border, a process potentially facilitated by the EU.

\footnotetext{
${ }^{1}$ P. Mitchell, 'Party competition in an ethnic dual party system' (1995) Ethnic and Racial Studies, 18:4, 773-96.

${ }^{2}$ M. Murphy and K. Hayward, 'Party politics and the EU in Ireland, North and South', in K. Hayward and M. Murphy (eds.), The Europeanisation of Party Politics in Ireland, North and South (Abingdon: Routledge, 2010), p. 3.
} 
Although religious references have markedly declined in DUP discourse during the party's post 1998 modernisation and expansion, ${ }^{3}$ the party's founder, Rev. Ian Paisley, was vocally opposed to Europe on the grounds that it was a Roman Catholic plot to extend Vatican influence across the continent, and that the EEC was foretold in Biblical prophecies of the End Times. ${ }^{4}$ At the same time, while not hiding his religious views, Paisley voiced secular Eurosceptic arguments. ${ }^{5}$ Paisley topped the polls in the first European Parliament (EP) election in 1979 and every subsequent one until his last in 1999. Paisley's success indicated how voters treated those elections - the only ones in which Northern Ireland was a single constituency as proxy constitutional referendums, and unionists' wish to support the candidate who was the self-styled stoutest defender of unionism. ${ }^{6}$

Although Paisley understood his role as a Member of the European Parliament (MEP) as allowing him to oppose Europe from the inside, the position became a key means for the DUP's co-operation with European institutions. This approach was summed up by Paisley in a well-known remark: 'I'm going to get all I can for Ulster, every grant we can possibly get our hands on. Then when we have milked the cow dry, we are going to shoot the cow'. ${ }^{7}$ Such pragmatism was evident in how Paisley, John Hume of the Social Democratic and Labour Party (SDLP) and the UUP's Jim Nicholson worked closely to secure funding for Northern Ireland. ${ }^{8}$

After initial opposition to joining the EEC, the UUP accepted the practical benefits of co-operating with other states within a European framework. Murphy sums up the party's

\footnotetext{
${ }^{3}$ J. Tonge, M. Braniff, T. Hennessey, J. McAuley and S. Whiting, The Democratic Unionist Party: From Protest to Power (Oxford: Oxford University Press, 2014).

${ }^{4}$ G. Ganiel, (2010) 'Battling in Brussels: The DUP and the European Union', in K. Hayward and M. Murphy (eds.), The Europeanisation of Party Politics in Ireland, North and South (Abingdon: Routledge, 2010), pp. 161-63.

${ }^{5}$ D. Cooke, Persecuting Zeal: A Portrait of Ian Paisley (Dingle: Brandon, 1996), p. 189.

${ }^{6}$ S. Bruce, Paisley: Religion and Politics in Northern Ireland (Oxford: Oxford University Press, 2007), p. 109.

${ }^{7}$ J. Brewer and G. Higgins, Anti-Catholicism in Northern Ireland, 1600-1998: The Mote and the Beam. (Basingstoke: Palgrave Macmillan, 1998), p. 108.

${ }^{8}$ G. Laganà, The Genesis of the Europeanisation of the Northern Ireland Peace Process. PhD Thesis, NUI Galway, 2018.
} 
orientation to Europe as 'pragmatic but lacking a wholehearted embrace of fundamental EU principles'. ${ }^{9}$ Again, that pragmatism focused on harnessing the benefits of Europe to Northern Ireland, given its status as a peripheral, conflict-affected and agriculture-dependent region. The UUP held a seat in the EP from the first European election in 1979 until losing it in 2019. In elections to the EP, the DUP presented its Euro-scepticism as a selling point, over the UUP's more moderate stance. However, whether this made any impact on voters is unclear since all votes in Northern Ireland tend to be fought on the peace process and/or constitutional question. $^{10}$

Sinn Féin's initial attitude to the EU stemmed from a similar logic to that of the DUP. Surrendering any power to a supra-national body like the EU was highly suspect to a movement dedicated to attaining and maintaining national freedom. However, republicanism's attitude to European integration had a marked, though softening, leftist, anti-imperialist tenor. Republicans opposed Ireland's membership of the EEC, viewing the latter as threatening Irish sovereignty and neutrality, and as an essentially elitist, capitalist project. ${ }^{11}$ These concerns have remained constant in Sinn Féin's European policies; notably, it campaigned against the Nice Treaty in the early 2000s on the grounds that an emboldened European defence and security policy compromised Irish neutrality, and new decision-making rules disempowered individual states. ${ }^{12}$ But overall, the party has gradually accepted the Union, moving from being Eurosceptic to 'Euro-critical'. ${ }^{13}$ Elections to the EU have offered an additional - and crucially, allIreland - platform for party growth, though this did not bear fruit until 2004 when the party won a seat in Dublin and took John Hume's seat in the North.

\footnotetext{
${ }^{9}$ M. Murphy, 'Pragmatic politics: The Ulster Unionist Party and European Union' in K. Hayward and M. Murphy (eds.), The Europeanisation of Party Politics in Ireland, North and South (Abingdon: Routledge, 2010), pp.177.

${ }^{10}$ Murphy, 'Pragmatic politics'.

11 A. Maillot, 'Sinn Féin's approach to the EU: Still more 'critical than "engaged”?', in K. Hayward and M. Murphy (eds.), The Europeanisation of Party Politics in Ireland, North and South (Abingdon: Routledge, 2010).

${ }^{12}$ A. Maillot, New Sinn Féin: Irish Republicanism in the Twenty-First Century (Abingdon: Routledge, 2005).

${ }^{13}$ M. L, McDonald, 'A New Ireland in a new Europe', IACES Annual Lecture, Trinity College Dublin, 30 November 2018.
} 
The SDLP has been the most unequivocally pro-European party in Northern Ireland. From the beginning of 'the Troubles', John Hume, leader from 1979 to 2001, 'drew upon the integrationist project as an ideological resource, hoping to evoke new ways of thinking about the Northern Ireland problem' ${ }^{14}$ Far from being conditional or pragmatic, the SDLP's support for Europe was rooted in a sense of shared values. The European model was instructive for Northern Ireland for several reasons, as summed up in Hume's final speech to the EP in 2004. One was that the achievement of peace between Germany and France in a relatively short time following the Second World War proved that peace was achievable in the most unpromising cases. A second reason was that the EU showed the benefits of building political relationships gradually through practical social and economic co-operation: '...spilling their sweat and not their blood. As they did so, they eroded the divisions of centuries'. ${ }^{15}$ A third was that it offered an example of political institutions that could both transcend national borders but accommodate and respect diverse identities.

Hume believed these principles of European co-operation were mirrored in the 1998 Agreement and would have a similar transformational impact. ${ }^{16}$ Hume was pivotal in raising the profile of Northern Ireland as a region and as an unresolved political question within the European institutions and, as noted, worked with fellow MEPs from Northern Ireland to secure financial support. In EP elections, the SDLP campaigned on European issues to a much greater extent than other Northern Ireland parties, demonstrating its interest and competence in the European arena as a forum for addressing the concerns of voters and not just the playing out of local battles. ${ }^{17}$

\footnotetext{
${ }^{14}$ P.J McLoughlin, 'The SDLP and the Europeanisation of the Northern Ireland problem', in K. Hayward and M. Murphy (eds.), The Europeanisation of Party Politics in Ireland, North and South (Abingdon: Routledge, 2010), p. 193.

${ }^{15}$ Hume quoted in S. Farren (ed.), John Hume in His Own Words (Dublin: Four Courts Press, 2017), p. 316.

${ }^{16}$ Farren, John Hume.

${ }^{17}$ P.J McLoughlin, 'The SDLP and the Europeanisation of the Northern Ireland problem', in K. Hayward and M. Murphy (eds.), The Europeanisation of Party Politics in Ireland, North and South (Abingdon: Routledge, 2010), pp.191.
} 
The Alliance Party also regarded itself as ideologically in sync with the European Union through a shared internationalism, liberal outlook and unifying and reconciliatory ethos. Significantly for Alliance, Europe offered people in the north of Ireland an overarching identity beyond the traditional binaries of unionism and nationalism, Irish and British. These identities, the party believed, needed to be transcended in order for a reconciled and stable society to emerge. ${ }^{18}$ At the same time, the regional, as opposed to national, emphasis within the EU was also appealing to Alliance, a party which had always been strongly devolutionist and which saw the unifying potential of a shared regional identification. ${ }^{19}$ Traditionally, the fifth largest party, Alliance was never in serious competition for an EP seat until its popular leader, Naomi Long, capitalised on Brexit dissatisfaction to win a seat at Northern Ireland's last European poll in 2019.

\section{The parties' Brexit policies}

The possibility that the UK's departure from the EU could undermine peace and stability in Northern Ireland was a very minor point of debate in the Brexit referendum campaign, especially in Britain where the focus was on immigration and the economy. The decision of the then Secretary of State for Northern Ireland, Theresa Villiers, to support the campaign to leave the EU led to - mainly nationalist - calls for her resignation on the grounds that such as position was incompatible with her responsibility to uphold the Good Friday Agreement. The former Prime Ministers, John Major and Tony Blair, campaigned jointly to highlight what they saw as Brexit's threat to the peace process. Pro-Brexit advocates rejected this as

\footnotetext{
${ }^{18}$ D. Mitchell, 'Non-nationalist politics in a bi-national consociation: the case of the Alliance Party of Northern Ireland' (2018) Nationalism and Ethnic Politics, 24:3, 336-47.

${ }^{19}$ S. Farry and S. Neeson, 'Beyond the Band-Aid approach: an Alliance Party perspective upon the Belfast Agreement' (1999) Fordham International Law Journal, 22:4, 1221-49.
} 
scaremongering. Yet all these discussions failed to capture widespread public concern since virtually no-one expected a Leave result. ${ }^{20}$

The DUP was the only main Northern Ireland party to support the Leave campaign. However, the party apparently gave little consideration to the impact of a potential Leave result, especially on the Union. As research by Murphy and Evershed shows ${ }^{21}$ the nature of the EU was not at the forefront of many party figures' thinking. Rather, supporting Leave was viewed as an opportunity to assert Britishness, rediscover the party's Paisleyite opposition to Europe, and take an opposing stance to that of its traditional rivals, the nationalist parties, Alliance, and the British and Irish governments. Supporting Brexit was an 'ideological free-ride' 22 - no-one in the party foresaw having to deal with the repercussions of their policy.

After the referendum, the party's approach was characterised by two concerns: 1) a hard Brexit for the whole of the UK involving leaving the Single Market and Customs Union; and 2) avoiding any weakening of the link between Northern Ireland and Britain. These were widely viewed as incompatible because the EU, in concert with Ireland, was resolutely opposed to a hard border in Ireland, meaning that either the UK needed to pursue a soft Brexit, or Northern Ireland had to be decoupled from the UK and remain aligned to Ireland and the EU. The DUP unexpectedly found itself with extraordinary influence when the June 2017 election, called by Theresa May in order to strengthen her negotiating hand with Europe, left the Conservatives dependent on the DUP for a secure majority. ${ }^{23}$

Most dramatically, the DUP used its newfound power to stop a UK-EU Withdrawal Agreement at the eleventh hour in December 2017 on the grounds that it could create a 'border

\footnotetext{
${ }^{20}$ On the campaign see G. McCann and P. Hainsworth, 'Brexit and Northern Ireland: the 2016 referendum on the United Kingdom's membership of the European Union' (2017) Irish Political Studies 32:2, 327-42.

${ }^{21}$ M. Murphy and J. Evershed, 'Between the devil and the DUP: the Democratic Unionist Party and the politics of Brexit' (2019) British Politics. https://doi.org/10.1057/s41293-019-001263.

${ }^{22}$ B. O'Leary, 'Postscript: New British Questions or 2019 And All That!' (2018) Ethnopolitics, 17:3, 325-333 at 229.

${ }^{23}$ J. Tonge, 'Supplying confidence or trouble? The deal between the Democratic Unionist Party and the Conservative Party (2017) The Political Quarterly 88, 412-16.
} 
in the Irish Sea'. The party consistently opposed the so-called 'backstop', the proposed provision in which Northern Ireland and the entire UK would remain aligned to whatever EU rules were necessary to avoid a hard border and which would come in to effect if the EU and UK could not agree a trade deal that could maintain an open border. This opposition placed the party strikingly at odds with the local business and farming communities, with whom the Democratic Unionists usually sought to remain in step. The party opposed May's final Withdrawal Agreement in 2019. The DUP's influence came to an end in December of that year following Boris Johnson's emphatic election victory. Johnson and the DUP had previously courted each other as fellow unionists during the May period, yet Johnson attained his deal with the EU (and the support of Parliament) by overriding the DUP's concerns and conceding a 'border in the Irish sea' in order to prevent a hard land border.

The Ulster Unionist Party supported Remain, but, reflecting the party's longstanding ambivalence on Europe, the resolution adopted by the party executive contained two caveats: that the UK should continue to press for reform of the EU and oppose further political union, and that individual party members could vote as they wished. ${ }^{24}$ Party leader Mike Nesbitt's reasons for supporting continued EU membership included the threats to business and to continued peace funding, and the likelihood of a hard border in Ireland, but also two more unionist-informed augments. Brexit could lead to another referendum on Scottish independence, and the prevailing settlement with the EU was advantageous: 'the UK retains a massive degree of sovereignty already. We were not forced into the Eurozone. We did not have to sign up to the Schengen Agreement'. ${ }^{25}$

After the referendum, however, this stark policy difference with the DUP faded. The Ulster Unionists accepted the result as a UK-wide decision ('the days of being a "Remainer'

\footnotetext{
${ }^{24}$ M. Nesbitt, 'EU Poll critical to Northern Ireland's security and prosperity', Belfast Telegraph, 7 March 2016 https://www.belfasttelegraph.co.uk/opinion/mike-nesbitt-eu-poll-critical-to-northern-irelands-security-andprosperity-34516508.html 25 Nesbitt, 'EU poll critical'.
} 
or a "Brexiteer" are over') and argued that the Northern Ireland Executive should seek to limit the economic impact of Brexit in Northern Ireland. ${ }^{26}$ Yet as the Brexit debate came to focus on the 'backstop' in 2017-18, the UUP saw the same constitutional dangers as those perceived by the DUP. The Ulster Unionists also opposed the Johnson deal, but made sure to point out what they saw as the DUP's responsibility in bringing matters to this point.

From the outset, Sinn Féin, the SDLP and Alliance Party made clear that they would support remaining in the EU. Their arguments exhibited common themes, both pre- and postreferendum. Sinn Féin reiterated its criticism of the EU, which, the party said, was 'moving away from a social Europe to very much a right-wing agenda' ${ }^{27}$ But the solution was to pursue change from within the structures of Europe rather that support a British Tory exit project. Furthermore, Brexit risked economic damage to the island, undermining labour rights, and causing disruption at the border. Should the UK vote to leave, the party called for a border poll, and if the North voted to remain while the UK overall voted to leave, Sinn Féin advocated the North staying in the EU. ${ }^{28}$ After the referendum result, Sinn Féin calls for a border poll were immediate. The party's Brexit policy focussed on seeking 'special status' for Northern Ireland which could preserve access to the Single Market and the Customs Union, and ensure the maintenance of the Common Travel Area, EU standards, and EU funding streams. ${ }^{29}$

The SDLP's pro-Remain campaign was imbued with its strong commitment to the European project and its impact on political relationships in Ireland: 'We are a party with Europe and the Good Friday Agreement at our core' ${ }^{30}$ Following the referendum, the SDLP

\footnotetext{
${ }^{26}$ Ulster Unionist Party, A Vision for Northern Ireland Outside the EU, 2016, p. 1 https://uup.org/assets/images/a\%20vision\%20for\%20ni\%20outside\%20the\%20eu.pdf

${ }^{27}$ S. Bardon, 'Sinn Féin to campaign against Brexit in EU referendum', Irish Times, 24 December 2015, https://www.irishtimes.com/news/politics/sinn-f\%C3\%A9in-to-campaign-against-brexit-in-eu-referendum1.2476720

${ }^{28}$ Bardon, 'Sinn Féin to campaign', 2015.

${ }^{29}$ Sinn Féin, The Case for the North to Active Designated Special Status. n.d. https://www.sinnfein.ie/files/2016/The_Case_For_The_North_To_Achieve_Special_Designated_Status_Within _The_EU.pdf

${ }^{30}$ SDLP, SDLP Westminster Election Manifesto, 2017, p. 2. https://cain.ulster.ac.uk/issues/politics/docs/sdlp/sdlp_2017-05-30_ge-man.pdf
} 
also called for special status for the North, but emphasised the potential of the 1998 Agreement structures to facilitate this, especially Strands Two and Three which dealt with the cross-border co-operation and the British-Irish relationship that stood to be undermined by Brexit. ${ }^{31}$ The party took a more cautious approach on a border poll to Sinn Féin; it supported such a referendum but highlighted that considerable more debate and clarity on what would be proposed was needed first.

To the Alliance Party, the prospect of Brexit was invidious and polarising, especially given the fact that a majority in Northern Ireland - the polity traditionally prioritised by Alliance over Ireland and the UK - had voted against it. Like the nationalist parties, Alliance advocated special arrangements that would allow Northern Ireland continued participation in as much of the EU as possible, regardless of what the rest of the UK opted for, and it contended that access to both the EU and UK single markets could create considerable opportunities: 'Northern Ireland only works based upon sharing and interdependence. Whilst it remains part of the UK in line with the Principle of Consent, it is important that people can live their lives and do business without impediment on both a north-south and east-west axis' ${ }^{32}$

The nationalist parties, along with Alliance and the Greens, showed a united front at moments during the post-Brexit period, making the case for the 'backstop' as the least bad option for Northern Ireland. A formal Remain electoral alliance did not materialise, but in the general election of December 2019, all of these parties except Alliance (which had long pledged opposition to any form of electoral pact) stood aside in constituencies to boost the Remain candidate who was thought most likely to be successful. These parties were also critical of the DUP's close relationship with the Conservatives, not only due to clashing

\footnotetext{
${ }^{31}$ SDLP, 'SDLP Westminster Election Manifesto, 2017', p. 6.

${ }^{32}$ Alliance Party, 'Bridges not borders: Northern Ireland in the Single Market, Alliance Party proposals', 2017, p. 1 , https://d3n8a8pro7vhmx.cloudfront.net/allianceparty/pages/3583/attachments/original/1537972637/bridges-notborders-northern-ireland-in-the-single-market.pdf?1537972637
} 
policies on Europe, but because that relationship was not thought to be conducive to political stability in Northern Ireland and the British government's role as impartial guarantor of the Agreement. Sinn Féin made much of the instability at Westminster, calling the Commons the 'House of Chaos' ${ }^{33}$ Yet the knife-edge parliamentary drama which began in London after the June 2017 Westminster election placed Sinn Féin under pressure on the matter of abstention, since it appeared that the party's eight MPs could have made the difference in some key votes on Europe.

Despite the heatedness of the Brexit debate in Northern Ireland politics, the parties were, in fact, conspicuous by their powerlessness. Except for the DUP which enjoyed influence for two and a half years at Westminster, the Northern Ireland parties' input in the Brexit process was limited to persuasion. This was obviously frustrating for the Remain parties who represented the views of the pro-Remain majority who voted in referendum, although those parties' views were very successfully represented by the Irish government which had considerable sway in the EU27. The next section examines in greater detail Brexit's constitutional meaning and implications in Northern Ireland in the context of the constitutional provisions of the Agreement.

\section{The constitutional question: Brexit's challenge to the Good Friday Agreement}

As has been noted, unionists have traditionally been more Euro-sceptic than nationalists. Yet, as Hayward and Murphy note, prior to Brexit this difference of opinion was not problematic 'because it did not demand deeper consideration of complex political questions related to UK

\footnotetext{
${ }^{33}$ Belfast Telegraph, 'Brexit: Sinn Féin hits out at 'House of Chaos' after MPs back Brexit delay amendment', 19 October 2019, https://www.belfasttelegraph.co.uk/news/northern-ireland/brexit-sinn-Féin-hits-out-at-houseof-chaos-after-mps-back-brexit-delay-amendment-38611553.html
} 
sovereignty, the unity of the UK and constitutional issues'. ${ }^{34}$ The 2016 vote on membership of Europe raised questions about self-determination, legitimacy, and power in Northern Ireland from which much of society had been trying move away for almost a generation since the Good Friday Agreement. That document offered a political formula which could allow the national question - over which militants had been fighting and which had prevented consensus-based political institutions - to be 'parked', freeing Northern Ireland's leaders to cooperate on socioeconomic matters. As the Agreement itself stated: 'We acknowledge the substantial differences between our continuing and equally legitimate political aspirations. However, we will endeavour to strive in every practical way towards reconciliation'. ${ }^{35}$

The substance of the Agreement's formula comprised a core trade-off: unionists' primary success was continuing UK sovereignty over Northern Ireland (based on the principle of majority consent) while nationalists' primary success was reform of the governance of Northern Ireland (based on cross-community consent). There were, then, two 'standards of legitimacy' in the accord, majoritarian for constitutional matters, cross-community for institutional matters. ${ }^{36}$

The principle of majority consent was clearly a mechanism for managing, not resolving, the constitutional conflict. But in theory this principle allowed both sides to retain their aspirations while preventing both sides from realising those aspirations without taking account of the identity and fears of the other side. Unionists, in order to preserve the Union, would have to ensure that Northern Ireland was a place to which nationalists could feel belonging, while nationalists, to attain Irish unity, would have to convince unionists of the merits of a united

\footnotetext{
${ }^{34}$ K. Hayward and M. Murphy, 'The EU's influence on the peace process and Agreement in Northern Ireland in light of Brexit (2018) Ethnopolitics 17:3, 276-291 at 278.

${ }^{35}$ Agreement reached in the multi-party negotiations [Good Friday/Belfast Agreement], 1998, p. 1.

${ }^{36}$ N. Porter, The Elusive Quest: Reconciliation in Northern Ireland (Belfast: Blackstaff, 2003), pp. 218-9; J.

Ruane and J. Todd, 'The Belfast Agreement: context, content, consequences', in J. Ruane and J. Todd (eds.), After the Good Friday Agreement: Analysing Political Change in Northern Ireland (Dublin: University College Dublin Press, 1999), pp. 20-21.
} 
Ireland. As it turned out, this kind of generous convergence was rare during the tumultuous implementation of the Agreement. Each side held to its own standard of legitimacy as trumping the other's. Thus, for instance, in the relentless post-Agreement dispute over the display of state flags and emblems, unionists argued that the majoritarian standard on sovereignty meant that state symbolism should be unequivocally British. Nationalism countered that state symbolism should have cross-community legitimacy. ${ }^{37}$

Nevertheless, the basic fact that the constitutional status of Northern Ireland depended on majority consent was uncontested after 1998. Indeed, Guelke notes that the Agreement's constitutional provisions resonated with the post-Cold War international climate on selfdetermination which was sympathetic to democratically endorsed secession. ${ }^{38}$ The removal of the territorial claim on the North from the Irish constitution - endorsed by the people of the Republic and Northern nationalists - ended any doubt over Northern Ireland's legitimacy as an appropriate unit of self-determination. Pro-Agreement unionists welcomed the enshrining of the principle of consent as a bulwark against further nationalist advance since these unionists did not envisage a majority in favour of unity ever developing in the future. The antiAgreement DUP was more pessimistic, arguing that consent made territorial claims equivalent, and the Union a hostage to demographics. But later, the DUP accepted consent as a major gain. ${ }^{39}$ In sum, despite conflicts over how sovereignty should be manifested, the Agreement's popularly endorsed constitutional arrangements did succeed to a great extent in what they were intended to do: removing the national issue from everyday political argument.

\footnotetext{
${ }^{37}$ D. Mitchell, Politics and Peace in Northern Ireland: Political Parties and the Implementation of the 1998 Agreement. (Manchester: Manchester University Press, 2015).

${ }^{38}$ A. Guelke, 'Northern Ireland, Brexit, and the Interpretation of Self-Determination' (2019) Nationalism and Ethnic Politics 25:4, 383-399, DOI: 10.1080/13537113.2019.1678307

${ }^{39}$ Peter Robinson praised how 'the right of self-determination for the people of Northern Ireland is a fundamental cornerstone of the political process'. P. Robinson, 'Reflections on Irish unionism', Speech in Iveagh House, Dublin, 29 March 2012, CAIN web Service, http://cain.ulst.ac.uk/issues/politics/docs/dup/pr290312.htm, accessed 23 January 2014.
} 
At the same time, the principle of cross-community consent was also increasingly embedded, becoming a taken-for-granted feature of governance in the North. The DUP, which had previously opposed power-sharing, entered government with Sinn Féin in 2007. While the DUP showed little warmth for its partners in government, the principle of partnership was nonetheless accepted. The party became a frequent user of the 'petition of concern' - the mechanism designed to ensure that decisions had the support of both unionists and nationalists. Even the anti-peace process Traditional Unionist Voice (TUV) accepted the need for government to have cross-community composition, showing the degree to which the principle had been widely accepted and internalised.

Into this context, governed by these notions of consent, came Brexit. The challenges posed by the Brexit vote may be demonstrated by testing it according to the two standards of legitimacy in the Agreement. It fails on both counts. First, the vote did not have majority legitimacy in that fifty-six per cent of voters in Northern Ireland opposed leaving the EU. Brexit, of course, was a UK-wide vote which did not require majority support in Northern Ireland or the other devolved regions. This was established in early 2017 when, in response to legal challenges, UK Supreme Court judges ruled that Brexit did not need the consent of the Scottish Parliament and Welsh and Northern Ireland assemblies, and furthermore, that while the 1998 Agreement's principle of consent gave people in Northern Ireland the right to determine whether Northern Ireland remained in the UK, it did not give them the power to determine whether Northern Ireland remained in the EU. ${ }^{40}$ The DUP, responding to the charge that Brexit, and DUP policy, lacked democratic legitimacy, repeated simply that the referendum was held on an all-UK basis. Since the party had supported, and welcomed, Brexit as a reassertion of UK sovereignty, this was a comfortable argument to make, even if it flew

\footnotetext{
${ }^{40}$ D. Casciani, 'Supreme Court on NI', 24 January 2017. https://www.bbc.co.uk/news/uk-northern-ireland$\underline{38728434}$
} 
somewhat in the face of the ethos of partnership and consensus which was meant to govern the political arrangements in which the DUP had taken part for the previous decade. Remain unionists' imagined community also comprised the peoples of the UK, so it was ideologically and emotionally possible for them to acquiesce to the result. This was the approach taken by the UUP. ${ }^{41}$

But for nationalists, most of whom were Remainers, the UK-wide vote had a different meaning. They cared considerably less about the views of voters in Britain and faced the prospect of being cut off from their co-nationals in the Republic by a hard border. The territorial hue of the referendum results also drew a sharp contrast between Ireland, whose people North and South were markedly pro-European, and England and Wales, whose people were much less so, thus arguably highlighting divergent political cultures on the two islands and playing into separatist Irish nationalist assumptions and arguments that English power in Ireland was not only historically unfortunate but actually incongruent with the sensibilities of the people in Ireland.

On the second standard of legitimacy - cross-community - the Brexit vote also failed. Brexit did not have cross-community consent. Unfortunately for community relations, it did not have the shared unconsent of unionists and nationalists either - it was mostly supported by unionists. Again, Brexit did not require cross-community consent and it did not purport to directly impede on the region's internal arrangements. Yet this was little comfort to Remainers in the North, given fears that, by reintroducing a hard border, Brexit would affect the social

\footnotetext{
${ }^{41}$ However, later, unionists became much more concerned about the consent of people in Northern Ireland. When the 'backstop' and subsequently Johnson's withdrawal deal appeared to edge Northern Ireland away from Westminster and closer to Europe, the unionist parties opposed these arrangements on the grounds that they would supposedly breach the Good Friday Agreement's principle of majority consent to change in the status of Northern Ireland (see K. Hayward and D. Phinnemore, 'Breached or protected? The "principle" of consent in Northern Ireland and the UK government's Brexit proposals’, LSE Brexit Blog, 9 January 2019. https://blogs.lse.ac.uk/brexit/2019/01/09/breached-or-protected-the-principle-of-consent-in-northern-irelandand-the-uk-governments-brexit-proposals/).
} 
and economic existence of thousands of people. Brexiteers argued that Europe was largely irrelevant to the Good Friday Agreement and that the accord could not be altered by leaving the EU. But the Agreement said little about the EU and, indeed, the border, because in the climate in which the deal was concluded, it did not need to. The thrust of the accord was to bring each of the estranged partners in John Hume's three 'strands' - unionists and nationalists, North and South, UK and Ireland - into closer fellowship through new institutions. It was assumed in 1998 that all those institutions and each of the three dyads of cooperation would enjoy the canopy of Europe.

Thus, the EU would ease unionist-nationalist reconciliation through providing an overarching identity, facilitate North-South co-operation through obviating the need for border checks and harmonising policy, and sustain British-Irish connections through shared membership of, and interests in, European institutions. The removal of Europe from the equation posed significant threats to all three relationships; hence the seriousness with which nationalists and others took the fact that they had not consented to that removal. Moreover, cross-community power-sharing had been welcomed in 1998 by nationalists as a bulwark against Westminster influence in northern Irish affairs. The fact of the Union had been made much more palatable by the presence of locally responsive and locally accountable government, linked of course, to North-South institutions. In this context, an encroachment by Westminster, of the magnitude of Brexit, was anathema.

At bottom, regardless of whether it was technically or legally defensible, Brexit demonstrated to people in Northern Ireland that a major change in the governance of the region could occur without their consent, either majoritarian or parallel. In a cohesive society, such a scenario may not have proved to be problematic. But in a region with fresh memories of misrule permitted and propagated by the national government, and that possessed, in the principle of consent's option of a border poll, a mechanism to change which state ruled, the lack of consent 
was extremely destabilising. The uncertainty created by Brexit, combined with the suspension of 'normal' political discourse due to the collapse of the power-sharing institutions, opened the space for a new phase of fundamental, existential questioning in and about Northern Ireland.

\section{The emergence of a new constitutional debate}

At the outset, the emerging public discussion on Irish unity post-Brexit should be placed in the context of that discussion's near total absence pre-Brexit. This absence was surprising given the extent to which pro-Agreement republicans supported the Good Friday Agreement on the basis that it could create a transitional dispensation leading to the longstanding republican goal of a thirty-two-county Irish state. Sinn Féin argued in 1998 that the 'dynamic operation of allIreland structures', combined with all-island economic integration, the empowerment of nationalist culture and identity through the equality agenda, and demographic change in the North, would erode the Irish border and detach the six-counties from the UK. ${ }^{42}$ However, in the period 1998 to 2016, it is hard to identify any unequivocal supporting evidence for Sinn Féin's transitional interpretation of the Agreement.

Indeed, observers highlighted that none of Sinn Féin's purported island-unifying processes would necessarily lead in that direction. The institutions comprising the Agreement's all-Ireland dimension were limited in scope and possessed no 'dynamic' of expansion. Crossborder social and economic co-operation would increase but were not necessarily a channel to political union. The equality agenda would make Catholic-nationalist identity more visible, but it would do so within Northern Ireland. Sinn Féin did argue that the transition would require

\footnotetext{
${ }^{42}$ M. McGuinness, 'Leadership address by Gerry Adams MP and Martin McGuinness MP', Sinn Féin Ard Fheis, Dublin, 18 April 1998, Northern Ireland Political Collection, Linenhall Library, Belfast p. 14.
} 
its own political growth on both sides of the border, and this was a realistic prospect. But the level of that electoral success and how exactly political strength would catalyse constitutional change in Ireland were again unclear. ${ }^{43}$

On the unionist side, there did exist a widespread post-Agreement perception that they were the losers in the peace process and that their culture and the British character of Northern Ireland were under continuous republican assault. ${ }^{44}$ Yet objectively, on the constitutional question, unionists appeared to be successful. While the Northern Catholic population was growing, the number of people desiring a united Ireland remained small. Indeed, in the 2015 Northern Ireland Life and Times Survey, only fourteen per cent of respondents thought a united Ireland to be the 'best long term policy' for the North, and just thirty-two per cent of Catholics. ${ }^{45}$ Accordingly, Irish unity, if not quite mythical, was a largely academic and abstract concept between 1998 and 2016.

The public discourse around Irish unity that began in 2016 was, first and foremost, initiated by the Brexit referendum result. But the way in which the Brexit process unfolded, as well as several other subsequent developments in UK and Ireland politics and society, reinforced and invigorated discussion. As noted, Sinn Féin, called, as it had pledged to, for a border poll immediately after the referendum. However, given the considerable uncertainty surrounding the if, how, and when of leaving the EU, plus the tumult caused in British politics, the possibility of constitutional change did not immediately take root in the public consciousness. The issue grew gradually.

An early indicator of potentially shifting attitudes at a grassroots level was the sharp increase in applications for Irish (i.e. EU) passports in the North, including among people of a

\footnotetext{
${ }^{43}$ N. Porter, The Elusive Quest, pp. 237-40; K. Bean, The New Politics of Sinn Féin (Liverpool: Liverpool University Press, 2007), pp. 174-216.

${ }^{44}$ On declining unionist support for the peace process see B. Hayes and I. McAllister, Conflict to Peace: Politics and Society in Northern Ireland Over Half a Century (Manchester: Manchester University Press, 2013). ${ }^{45}$ ARK. Northern Ireland Life and Times Survey, 2015 [computer file]. ARK www.ark.ac.uk/nilt [distributor], June 2016
} 
Protestant background who tended to hold British passports. In fact, Ian Paisley Jnr, avowed unionist Brexiteer, encouraged people to get an Irish passport for pragmatic reasons. ${ }^{46}$ This interest did not necessarily indicate that unionists were transformed by Brexit into nationalists in large - or even any - numbers. Yet it did show that many people of a Protestant-unionist background recognised the practical benefits of EU citizenship and did not want them removed, and that such people had no political or emotional aversion to possessing the passport of the Irish Republic, a state which had traditionally been an enemy to many northern unionists.

A more tangible boost for the Irish unity debate came in April 2017. While the end of partition presented itself to nationalists in the North as a potential solution to being taken, against their will, out of EU, it was not in fact certain that in the event of unification that the entire island of Ireland would automatically be inside the EU. Clarity came, however, when the EU declared, as part of its Brexit negotiation guidelines, that the North would indeed become part of the EU if Ireland was unified. ${ }^{47}$ This commitment, in combination with Brexit, represented the greatest leap forward for the project of Irish unity in decades. Henceforth, a border poll would not simply be about the attractiveness or otherwise of all-Ireland state, but membership of the EU.

Political events in Belfast also contributed to discussion regarding constitutional change. The failure of power-sharing in early 2017 and the prolonged political vacuum that followed was open to the interpretation that Northern Ireland, as constituted, was ungovernable. Specifically, nationalists could argue that unionists were incapable of affording equality to all in the North, and that the DUP in particular - despite ten years of power-sharing with Sinn Féin - was still unreconciled to the principle of partnership government. This was

\footnotetext{
${ }^{46}$ Belfast Telegraph, 'Apply for Irish passport if you can, advises DUP MP Ian Paisley’, 27 June 2016. https://www.belfasttelegraph.co.uk/news/northern-ireland/apply-for-irish-passport-if-you-can-advises-dup-mpian-paisley-34835231.html

${ }^{47}$ D. Staunton and P. Leahy, 'Brexit summit: EU accepts united Ireland declaration', Irish Times, 29 April 2017. https://www.irishtimes.com/news/world/europe/brexit-summit-eu-accepts-united-ireland-declaration-1.3066569
} 
the crux of Deputy First Minister Martin McGuinness's resignation letter which triggered what turned out to be a three-year suspension of government at Stormont. While Arlene Foster's refusal to step down as First Minister for an inquiry into the Renewable Heat Incentive (RHI) scandal ${ }^{48}$ was the immediate cause of the crisis, McGuinness made clear that this was, for his party, the final straw after numerous episodes which he claimed showed that 'The equality, mutual respect and all-Ireland approaches enshrined in the Good Friday Agreement have never been fully embraced by the DUP'.49

As the suspension continued, and especially after what appeared to be the final failure of talks to restore power-sharing February 2018, the Good Friday Agreement's partnership model appeared to be in unprecedented jeopardy. Meanwhile, campaigners, and most nonunionist parties, pressed for reform of abortion and same sex marriage laws, which were more conservative than those in Britain and Ireland. Yet Northern Ireland politics was unable to deliver change; reform of these issues was eventually enacted through Westminster in late 2019. ${ }^{50}$ Indeed, it was not in fact clear that, despite stated positions, the central political protagonists wanted Stormont to operate. The DUP was occupied with its newfound influence in London, while Sinn Féin was waiting for the constitutional implications of Brexit to become clear.

At the same time as politics was stagnating in Northern Ireland, the Republic of Ireland underwent dramatic political and social change. The 2015 referendum on same sex marriage was followed in 2018 by a plebiscite which supported the removal of the constitutional ban on abortion. These moves arguably signalled the end of the South's historic, Roman Catholicinfluenced social conservativism, and with it, one of unionism's central tenets. No longer could

\footnotetext{
${ }^{48}$ S. McBride, Burned: The Inside Story of the Cash for Ash Scandal and Northern Ireland's Secretive New Elite (Dublin: Merrion, 2019).

${ }^{49}$ M. McGuinness, 'Full text of Martin McGuinness resignation letter', Irish Times, 9 January 2017 https://www.irishtimes.com/news/politics/full-text-of-martin-mcguinness-s-resignation-letter-1.2930429.

${ }^{50}$ Sections 8 and 9 of the Northern Ireland (Executive Formation etc) Act 2019.
} 
Northerners argue that the Union offered a distinctly liberal and progressive context, in contrast to the Republic. Moreover, the economy south of the border was continuing a marked, postfinancial crisis (and pre-coronavirus crisis) recovery, placing in doubt unionism's longstanding contention that a united Ireland was not economically viable. An innovative Citizen's Assembly was also established in the Republic in 2016 to deliberate on selected, key public issues. The solidarity between Ireland and the EU27 during the Brexit process enhanced the image of Ireland as an esteemed, cooperative and outward-looking country. In 2020, Sinn Féin won the highest number of first preference votes in the Republic's general election. While the party campaigned mainly on socio-economic, rather than national/constitutional issues, this electoral breakthrough for the republican party naturally led to another fevered round of speechifying and media commentary that a united Ireland had come one step closer. ${ }^{51}$

Throughout the period following the Brexit referendum, the media naturally took a strong interest in opinion polls on Irish unity. The extent of attitudinal change varied depending on the methodologies of polls, with online surveys recording much greater change in favour of Irish unity than face to face interviews. ${ }^{52}$ One survey commissioned by academics showed that support among moderate nationalists for constitutional change would rise in the event of a hard Brexit: 'UKexit and the DUP's tactical and strategic response to it are sending liberal, bourgeois, educated Catholics toward the conviction that a reunified Ireland will better reflect their values, and their interests'. ${ }^{53}$ Nevertheless, according to the 2019 Northern Ireland Life and Times Survey results released in June 2020, the overall proportion of people desiring Irish unity as the best long term policy for Northern Ireland was still just twenty-two per cent. ${ }^{54}$

\footnotetext{
${ }^{51}$ For instance, the cover story in The Economist, 'Irish unification is becoming likelier', 13 February, 2020. https://www.economist.com/leaders/2020/02/13/irish-unification-is-becoming-likelier.

52 A. M. Gray, J. Hamilton, G. Kelly, B. Lynn, M. Melaugh and G. Robinson, Northern Ireland Peace Monitoring Report, Number 5 (Belfast, Community Relations Council, 2019).

53 J. Garry, B. O'Leary, K. McNicholl and J. Pow, 'The future of Northern Ireland: border anxieties and support for Irish reunification under varieties of UKexit', Regional Studies (2020), DOI: 10.1080/00343404.2020.1759796, p. 9.

${ }^{54}$ ARK. Northern Ireland Life and Times Survey, 2020 [computer file]. ARK www.ark.ac.uk/nilt [distributor], June 2020.
} 


\section{Political perspectives}

All these developments stimulated an ever-growing constitutional discussion within countless fora - academic conferences, research reports, traditional and social media, and community debates. The discussions focussed on several recurring questions. What would be unionists' reaction to a vote for Irish unity? What should be the required threshold for a border poll, a simple majority or weighted majority? What indicator should trigger a border poll? What form would a united Ireland take? Would a united Ireland be economically sustainable? What would be the effect of a vote for Scottish independence on Ireland? Are attitudes on unity changing? Are identities changing? In the wake of the Brexit vote, these questions were a novelty. By 2020, if not earlier, they were fixtures in political discourse. For the Northern Ireland political parties, this debate crystallised specific intra-bloc dilemmas.

Nationalism's main question was not in fact the nature of the possible 'new Ireland', something which all nationalists would have conceded had not even begun to take shape in public discussion and understanding. Rather, the question was the appropriate timing of a border poll. As noted, Sinn Féin was broadly more impatient than the SDLP, although in what circumstances, and with what degree of preparation, republicans wanted such a poll was not always clear. ${ }^{55} \mathrm{~A}$ further issue for nationalism, which links with the discussion above on models of consent, was raised by the late Séamus Mallon in his autobiography published in 2019. ${ }^{56}$ He proposed that for the sake of relationships in a united Ireland, the poll had to be run on a basis other than a simple majority, perhaps with some form of parallel consent. Leo Varadkar, the Taoiseach, made a similar comment on the undesirability of a narrow victory in

\footnotetext{
${ }^{55}$ M. Devenport, 'Is Sinn Féin changing its view on a border poll?', BBC news website, 31 July 2018. https://www.bbc.co.uk/news/uk-northern-ireland-45020294

56 S. Mallon with A. Pollak, A Shared Home Place (Dublin: Lilliput, 2019).
} 
a referendum. ${ }^{57}$ This view attracted derision from republicans, who pointed out that if a simple majority had been enough to prevent a united Ireland, then it should be enough to establish one. But regardless of the technical issues surrounding a border referendum, it was evident that there was some recognition within nationalism that constitutional change was not without risks.

By contrast, the debate within unionism centred on whether to participate - as nationalists invited them to participate - in debates on Irish unity. The commentary of key unionist figures provoked intense media interest and discussion. For instance, in the summer of 2018, the now former DUP leader Peter Robinson argued that unionism would be wise to engage in debates on Irish unity: 'I don't expect my own house to burn down but I still insure it because it could happen'. His party colleague, Sammy Wilson, rejected the comments, retorting that 'Preparing for a possible united Ireland is not an insurance policy against something unpleasant happening, it is an invitation to republican arsonists to come in and burn our house down' ${ }^{58}$ Robinson was, indeed, asking a lot from unionists; as journalist Sam McBride pointed out, 'it would be profoundly illogical for unionists to help with something which would make the end of the Union easier - unless they believed that they would inevitably lose such a plebiscite, which is not a commonly held view'. ${ }^{59}$ Some unionists were, however, concerned to at least put the unionist case in Irish unity discussions. On this, Mike Nesbitt, former UUP leader, was vocal, warning unionists repeatedly using the analogy of a frog in boiling water, unaware of the danger as the temperature gradually rises.

This kind of strategic debate was a perennial theme in unionism - should it engage with opponents, or isolate itself? But talk of Irish unity also raised deeper questions about unionist

\footnotetext{
${ }^{57}$ Belfast Telegraph, 'Poll: Varadkar says more than 50\% plus one needed in united Ireland poll - what do you think?', 17 October 2017, https://www.belfasttelegraph.co.uk/news/northern-ireland/poll-varadkar-says-morethan-50-plus-one-needed-in-united-ireland-poll-what-do-you-think-36235839.html

${ }^{58}$ G. Moriarty, 'Peter Robinson has delivered a “wake-up call” for unionism', Irish Times, 31 July 2018. https://www.irishtimes.com/news/ireland/irish-news/peter-robinson-has-delivered-a-wake-up-call-for-unionism1.3581228

${ }^{59} \mathrm{~S}$. McBride, 'If Sinn Féin waits for unionists to help plan Irish unity, it may wait a long time', 29 February 2020. https://www.newsletter.co.uk/news/politics/sam-mcbride-if-sinn-Féin-waits-unionists-help-plan-irishunity-it-may-wait-long-time-2004670
} 
identity. This came to the fore in April 2018 when, in an interview with the comedian Patrick Kielty as part of a documentary marking the twentieth anniversary of the Agreement, Arlene Foster said that if Ireland was united, she would probably leave the country. ${ }^{60}$ This provoked much public discussion and the question was put to other unionist figures. Notably, Sylvia Hermon, the independent (and, incidentally, the only pro-Remain unionist) MP, answered it with some emotion that whatever happened, she was going nowhere. Like her family, 'I'll be buried in the land that I love', ${ }^{61}$

Foster's attitude did express the fact that for many unionists, their unionism requires the privilege of living under British institutions and thus to assist the ending of those institutions' sovereignty in Northern Ireland would be nonsensical. Unionism, without the Union, was inconceivable. However, her remark also played into a longstanding image of unionists as somewhat unrooted, 'an unsettled people', 62 'under siege ${ }^{93}$ with 'a precarious belonging ${ }^{64}$, an image which Hermon appeared to wish to reject. In sum, as well as the more tangible matter of whether and how to take part in discussions on Irish unity, the prospect of constitutional change also asked unionists to consider the fundamentals of their identity and how these related to the circumstances around them, circumstances which were in flux.

\footnotetext{
${ }^{60}$ Irish News, 'Arlene Foster says 'I would probably move' if there was united Ireland', 5 April 2018. https://www.irishnews.com/news/brexit/2018/04/05/news/arlene-foster-says-i-would-probably-move-if-therewas-united-ireland-1297022/

${ }^{61}$ Interviewed on BBC The View, 4 May 2018. https://www.bbc.co.uk/programmes/p066805x

${ }^{62}$ S. McKay, Northern Protestants: An Unsettled People (Belfast: Blackstaff, 2000).

${ }^{63}$ A. Aughey, Under Siege: Ulster Unionism and the Anglo-Irish Agreement (London: Hurst, 1989).

${ }^{64}$ J. Dunlop, Presbyterians and the Conflict in Ireland: A Precarious Belonging (Belfast: Blackstaff, 1995).
} 


\section{Conclusion}

The constitutional debate will continue for the foreseeable future but its strength and progress depend on a number of factors. The first is whether the Irish government commences the 'preparations' for Irish unity that republicans wish to see. Despite some expectations, the programme for government agreed by the new Fianna Fáil/Fine Gael/Green Party coalition in June 2020 did not propose major initiatives in this area. Second is the unfolding of Brexit, which, with Boris Johnson's agreement with the EU in October 2019, entered a new phase. For the UK, the price of that accord was to allow a 'border in the Irish Sea', the precise nature of which is still to be determined. This avoids a hardening of the border in Ireland and thus to some extent assuages the nationalist anger which had been the dominant theme since 2016. A third factor is the performance of the Northern Ireland Executive, reformed in January 2020. If it remains stable and governs effectively, interest in constitutional change could wane. Fourth, the coronavirus crisis may have an impact. Notwithstanding Sinn Féin's argument that the virus proves the illogic of partition on a small Island, ${ }^{65}$ in fact, the shutdown may stall the momentum of the unity discussion, especially given the financial pressures it will impose into the future.

There has clearly been growth in support for Irish unity, but not enough to cause the British Secretary of State for Northern Ireland to call a border poll, the only legal mechanism through which one can be held. Given the demographic balance, a border poll will be decided by the non-unionist and non-nationalist bloc, a constituency which, as shown by election successes by the Alliance Party and Greens in 2019, is growing. Alliance continues to reject defining itself by the constitutional question, pledging to take part in debates on constitutional change, and that it will decide whether to take a position, and what position, if and when a

\footnotetext{
${ }^{65}$ J. McCormack, 'Coronavirus: Foster criticises Irish unity claim by Sinn Féin', 27 April 2020. https://www.bbc.co.uk/news/uk-northern-ireland-52445887
} 
border poll is called. ${ }^{66}$ This 'other' bloc will not be influenced by cultural and historical arguments but evidence of the socio-economic implications of constitutional arrangements. In theory, this should prompt the unionist and nationalist parties to finally demonstrate the spirit of persuasion and reassurance called for by the Agreement, and actually make the case for the Union and unity respectively, while simultaneously ensuring that these circumstances can accommodate and welcome all traditions and backgrounds. It remains to be seen whether unionists and nationalists are capable of such genuine outreach, rather than relying on demographic change and/or partisan political appeals, in their pursuit of their constitutional ideals.

${ }^{66} \mathrm{C}$. McCurry, 'Stephen Farry: Alliance will engage in discussions around border poll', Belfast Telegraph, 7 March 2020. https://www.belfasttelegraph.co.uk/news/northern-ireland/stephen-farry-alliance-will-engage-indiscussions-around-border-poll-39023549.html 